\title{
Pharmacology and Adverse Events of Emergency-Use Authorized Medication in Moderate to Severe COVID-19
}

\author{
Jen-Yu Hsu ${ }^{1} \mathbb{D}$, Yan-Chiao Mao ${ }^{2,3} \mathbb{D}^{\text {, Po-Yu Liu }}{ }^{1, *}$ and Kuo-Lung Lai ${ }^{4, *}$ \\ 1 Department of Internal Medicine, Division of Infectious Diseases, Taichung Veterans General Hospital, \\ Taichung 407219, Taiwan; b94401012@g.ntu.edu.tw \\ 2 Department of Emergency Medicine, Division of Clinical Toxicology, Taichung Veterans General Hospital, \\ Taichung 407219, Taiwan; doc1385e@gmail.com \\ 3 National Defense Medical Center, School of Medicine, Taipei 114201, Taiwan \\ 4 Department of Internal Medicine, Division of Allergy, Immunology and Rheumatology, Taichung Veterans \\ General Hospital, Taichung 407219, Taiwan \\ * Correspondence: pyliu@vghtc.gov.tw (P.-Y.L.); kllaichiayi@yahoo.com.tw (K.-L.L.); \\ Tel.: +886-4-23592525 (P.-Y.L. \& K.-L.L.)
}

Citation: Hsu, J.-Y.; Mao, Y.-C.; Liu, P.-Y.; Lai, K.-L. Pharmacology and Adverse Events of Emergency-Use Authorized Medication in Moderate to Severe COVID-19. Pharmaceuticals 2021, 14, 955. https://doi.org/ 10.3390/ph14100955

Academic Editors: Jean Jacques Vanden Eynde and Annie Mayence

Received: 1 September 2021

Accepted: 21 September 2021

Published: 23 September 2021

Publisher's Note: MDPI stays neutral with regard to jurisdictional claims in published maps and institutional affiliations.

Copyright: (c) 2021 by the authors. Licensee MDPI, Basel, Switzerland. This article is an open access article distributed under the terms and conditions of the Creative Commons Attribution (CC BY) license (https:// creativecommons.org/licenses/by/ $4.0 /)$.

\begin{abstract}
Some effective drugs have been approved or issued an Emergency Use Authorization for the treatment of COVID-19 in hospitalized patients, but post-market surveillance is warranted to monitor adverse events. We reviewed clinical trials and case reports in patients with moderate-to-severe COVID-19 infection who received remdesivir, baricitinib, tocilizumab, or sarilumab. The drug-specific pharmacokinetics, toxicity, and drug interactions are summarized in this study. Remdesivir and baricitinib are small-molecule drugs that are mainly metabolized by the kidneys, while tocilizumab and sarilumab are monoclonal antibody drugs with metabolic pathways that are currently not fully understood. The most common adverse events of these drugs are alterations in liver function, but serious adverse events have rarely been attributed to them. Only a few studies have reported that remdesivir might be cardiotoxic and that baricitinib might cause thromboembolism. Biological agents such as baricitinib, tocilizumab, and sarilumab could inhibit the pathway of inflammatory processes, leading to immune dysregulation, so the risk of secondary infection should be assessed before prescribing. Further recognition of the pathogenic mechanism and risk factors of adverse events is essential for optimizing treatment strategies.
\end{abstract}

Keywords: adverse event; baricitinib; COVID-19; remdesivir; sarilumab; tocilizumab

\section{Introduction}

As of 20 September 2021, there have been 228.4 million confirmed cases of coronavirus disease 2019 (COVID-19), which is caused by Severe Acute Respiratory Syndrome coronavirus 2 (SARS-CoV-2), and these cases include 4.7 million deaths [1]. The incidence and mortality rates were higher in certain regions and environments [2], and investigations on anti-coronavirus vaccines have been widely initiated [3]. However, for people infected with the disease, the choice of drugs is paramount. Patients without shortness of breath, dyspnea, or abnormal chest imaging are considered to have mild illness. Patients who develop dyspnea have at least moderate-severity disease, which often warrants hospitalization, and the need for oxygenation or ventilatory support indicates severe disease [4]. The U.S. Food and Drug Administration (US FDA) issued an Emergency Use Authorization (EUA) for casirivimab plus imdevimab, bamlanivimab plus etesevimab, and sotrovimab for the treatment of mild-to-moderate COVID-19 [5-7]. For moderate-to-severe infections, in addition to corticosteroids and emergency use of convalescent plasma [8,9], the US FDA approved or issued an EUA for remdesivir, remdesivir plus baricitinib, and tocilizumab 2020 [10-12].

In the development of a drug for moderate-to-severe infections, a major goal is to maximize its effectiveness while minimizing any safety issues, which is a delicate balancing 
act. The US FDA approved corticosteroids in July 2020 [8] and issued an EUA for emergency use of convalescent plasma in August 2020 [9] for hospitalized COVID-19 patients, but the available drugs for moderate-to-severe infections were still limited. The US FDA had issued but revoked its EUA for hydroxychloroquine and chloroquine in patients with severe COVID-19 in June 2020, noting that the known and potential toxicity exceeded expectations [13]. Lopinavir/ritonavir was also not recommended for hospitalized patients, mainly due to the lack of obvious efficacy and the high risk of drug interaction [14,15]. In COVID-19 patients treated with hydroxychloroquine, chloroquine, or lopinavir/ritonavir, the most commonly reported severe adverse event (AE) resulted from cardiotoxicity, such as QT interval prolongation. In contrast, other drugs such as remdesivir, baricitinib, tocilizumab, and sarilumab seemed to be effective but were less toxic [16-18].

\section{Chemical Structure and Molecular Properties}

Remdesivir, baricitinib, tocilizumab, and sarilumab have distinct chemical structures and molecular properties [19], as shown in Table 1, which give them their own unique mechanisms of action in the treatment of COVID-19. The US FDA approved remdesivir in intravenous injection form in October 2020 [10] based on the ACTT-1 clinical trial [20], and issued an EUA for baricitinib oral tablets in combination with remdesivir in November 2020 [11], based on the ACTT-2 clinical trial [17]. In June 2021, the US FDA issued an EUA for tocilizumab in intravenous injection form [12], based on the RECOVERY, EMPACTA, COVACTA, and REMDACTA clinical trials [21-24]. Sarilumab might have therapeutic effects, but research is still ongoing [18,25-29]. The completed and ongoing randomized controlled trials of these drugs are presented in Table 2. This study aimed to summarize the available evidence to address the pharmacokinetics, toxicity, and drug interactions of these four candidate drugs: remdesivir, baricitinib, tocilizumab, and sarilumab.

Table 1. The chemical structures and molecular properties of available drugs in moderate-to-severe COVID-19.

\begin{tabular}{|c|c|c|c|c|c|}
\hline Drugs & Type & Chemical Formula & Average Weight & $\begin{array}{l}\text { US FDA Labeled Indication } \\
\text { Other Than COVID-19 }\end{array}$ & $\begin{array}{l}\text { Possible Mechanisms in } \\
\text { Treatment of COVID-19 }\end{array}$ \\
\hline Remdesivir & Small Molecule & $\mathrm{C}_{27} \mathrm{H}_{35} \mathrm{~N}_{6} \mathrm{O}_{8} \mathrm{P}$ & $602.6 \mathrm{Da}$ & None & $\begin{array}{l}\text { The nucleotide analogue } \\
\text { inhibit viral nucleotide } \\
\text { synthesis to stop viral } \\
\text { replication. }\end{array}$ \\
\hline Baricitinib & Small Molecule & $\mathrm{C}_{16} \mathrm{H}_{17} \mathrm{~N}_{7} \mathrm{O}_{2} \mathrm{~S}$ & $371.4 \mathrm{Da}$ & $\begin{array}{l}\text { 1. Rheumatoid arthritis } \\
\text { (moderate to severe) }\end{array}$ & $\begin{array}{c}\text { The JAK inhibitor blocks } \\
\text { JAK-STAT signaling } \\
\text { pathway and } \\
\text { inflammatory response. }\end{array}$ \\
\hline Tocilizumab & $\begin{array}{l}\text { Monoclonal } \\
\text { antibody }\end{array}$ & $\mathrm{C}_{6428} \mathrm{H}_{9976} \mathrm{~N}_{1720} \mathrm{O}_{2018} \mathrm{~S}_{42}$ & $148,000.0 \mathrm{Da}$ & $\begin{array}{l}\text { 1. Cytokine release syndrome } \\
\text { 2. Juvenile rheumatoid arthritis } \\
\text { 3. Lung disease with } \\
\text { systemic sclerosis } \\
\text { 4. Rheumatoid arthritis } \\
\text { (moderate to severe) } \\
\text { 5. Systemic onset juvenile } \\
\text { chronic arthritis } \\
\text { 6. Temporal arteritis }\end{array}$ & $\begin{array}{c}\text { The IL-6 receptor } \\
\text { antagonist inhibit IL-6 } \\
\text { signaling pathway and } \\
\text { inflammatory response. }\end{array}$ \\
\hline Sarilumab & $\begin{array}{l}\text { Monoclonal } \\
\text { antibody }\end{array}$ & $\mathrm{C}_{6388} \mathrm{H}_{9918} \mathrm{~N}_{1718} \mathrm{O}_{1998} \mathrm{~S}_{44}$ & $150,000.0 \mathrm{Da}$ & $\begin{array}{l}\text { 1. Rheumatoid arthritis } \\
\text { (moderate to severe) }\end{array}$ & $\begin{array}{l}\text { The IL-6 receptor } \\
\text { antagonist inhibit IL-6 } \\
\text { signaling pathway and } \\
\text { inflammatory response. }\end{array}$ \\
\hline
\end{tabular}

Abbreviations: COVID-19, coronavirus disease 2019; Da, dalton; IL-6, Interleukin-6; JAK, Janus kinase; STAT, signal transducer and activator of transcription; US FDA, U.S. Food and Drug Administration. 
Table 2. The completed and ongoing randomized controlled trials of available drugs in moderate-to-severe COVID-19.

\begin{tabular}{|c|c|c|c|c|c|c|c|}
\hline Drugs & Trial Names & Trial Sites & Inclusion Criteria & Patient Numbers & Dosage & Efficacy & Safety \\
\hline Remdesivir & ACTT-1 [20] & $\begin{array}{c}\text { The United States } \\
(45 \text { sites), Denmark (8), } \\
\text { the United Kingdom (5), } \\
\text { Greece (4), Germany (3), } \\
\text { Korea (2), Mexico (2), } \\
\text { Spain (2), Japan (1), and } \\
\text { Singapore (1) }\end{array}$ & $\begin{array}{l}\text { Adults who were } \\
\text { hospitalized with } \\
\text { COVID-19 and had } \\
\text { evidence of lower } \\
\text { respiratory tract } \\
\text { infection }\end{array}$ & $\begin{array}{l}541 \text { assigned to the } \\
\text { remdesivir group and } \\
521 \text { to the placebo } \\
\text { group }\end{array}$ & $\begin{array}{c}\text { Remdesivir was } \\
\text { administered intravenously } \\
\text { as a 200-mg loading dose on } \\
\text { day } 1 \text {, followed by a 100-mg } \\
\text { maintenance dose } \\
\text { administered daily on days } \\
2 \text { through } 10 \text { or until } \\
\text { hospital discharge or death }\end{array}$ & $\begin{array}{l}\text { Remdesivir was superior to } \\
\text { placebo in shortening the time } \\
\text { to recovery; the mortality rates } \\
\text { were } 6.7 \% \text { with remdesivir and } \\
11.9 \% \text { with placebo by day } 15 \\
\text { (HR, } 0.55 ; 95 \% \text { CI, } 0.36 \text { to } 0.83 \text { ) } \\
\text { and } 11.4 \% \text { with remdesivir and } \\
15.2 \% \text { with placebo by day } 29 \\
\text { (HR, } 0.73 ; 95 \% \text { CI, } 0.52 \text { to } 1.03 \text { ) }\end{array}$ & $\begin{array}{l}\text { Serious adverse events were } \\
\text { reported in } 131 \text { of the } \\
532 \text { patients who received } \\
\text { remdesivir }(24.6 \%) \text { and in } \\
163 \text { of the } 516 \text { patients who } \\
\text { received placebo }(31.6 \%)\end{array}$ \\
\hline Tocilizumab & RECOVERY [21] & The United Kingdom & $\begin{array}{l}\text { Adults with COVID-19 } \\
\text { who had hypoxia } \\
\text { (oxygen saturation } \\
<92 \% \text { on air or requiring } \\
\text { oxygen therapy) and } \\
\text { evidence of systemic } \\
\text { inflammation } \\
\text { (C-reactive protein } \\
>=75 \mathrm{mg} / \mathrm{L} \text { ) }\end{array}$ & $\begin{array}{c}2022 \text { randomly } \\
\text { allocated to } \\
\text { tocilizumab and } 2094 \\
\text { to usual care }\end{array}$ & $\begin{array}{c}\text { Tocilizumab was given } \\
\text { intravenously as a dose of } \\
400-800 \mathrm{mg} \text {, followed by } \\
\text { either a second dose } 12-24 \mathrm{~h} \\
\text { later or not }\end{array}$ & $\begin{array}{l}\text { Tocilizumab was superior to } \\
\text { placebo in discharge from } \\
\text { hospital within } 28 \text { days ( } 57 \% \text { vs. } \\
50 \% \text { ); patients allocated } \\
\text { tocilizumab were less likely to } \\
\text { reach the composite endpoint of } \\
\text { invasive mechanical ventilation } \\
\text { or death (35\% vs. } 42 \% \text {; RR } 0.84 \text {; } \\
95 \% \text { CI } 0.77-0.92)\end{array}$ & $\begin{array}{l}\text { There were three reports of } \\
\text { serious adverse reactions } \\
\text { believed to be related to } \\
\text { tocilizumab: one each of } \\
\text { otitis externa, } \\
\text { Staphylococcus aureus } \\
\text { bacteremia, and lung } \\
\text { abscess, all of which } \\
\text { resolved with standard } \\
\text { treatment }\end{array}$ \\
\hline
\end{tabular}


Table 2. Cont

\begin{tabular}{|c|c|c|c|c|c|c|c|}
\hline Drugs & Trial Names & Trial Sites & Inclusion Criteria & Patient Numbers & Dosage & Efficacy & Safety \\
\hline Tocilizumab & EMPACTA [22] & $\begin{array}{l}\text { The United States } \\
\text { (45 sites), Brazil (6), } \\
\text { Peru (5), South Africa } \\
\text { (3), Kenya (2), } \\
\text { Mexico (2) }\end{array}$ & $\begin{array}{l}\text { Adults with COVID-19 } \\
\text { who were confirmed by } \\
\text { a positive polymerase- } \\
\text { chain-reaction test and } \\
\text { radiographic imaging }\end{array}$ & $\begin{array}{l}249 \text { randomly } \\
\text { allocated to } \\
\text { tocilizumab and } 128 \\
\text { to placebo }\end{array}$ & $\begin{array}{l}\text { Tocilizumab was given } \\
\text { intravenously as one or two } \\
\text { doses of } 8 \mathrm{mg} \text { per kilogram } \\
\text { of body weight (maximum } \\
\text { of } 800 \mathrm{mg})\end{array}$ & $\begin{array}{c}\text { Tocilizumab was superior to } \\
\text { placebo in the cumulative } \\
\text { percentage of receiving } \\
\text { mechanical ventilation or death } \\
\text { by day } 28(12.0 \% \text { vs. } 19.3 \% \text {; HR, } \\
0.56 ; 95 \% \text { CI, } 0.33 \text { to } 0.97) \text {; there } \\
\text { was no significant difference in } \\
\text { death from any cause by day } 28 \\
(10.4 \% \text { vs. } 8.6 \%)\end{array}$ & $\begin{array}{l}\text { Serious adverse events } \\
\text { occurred in } 38 \text { of } \\
250 \text { patients }(15.2 \%) \text { in the } \\
\text { tocilizumab group and } 25 \text { of } \\
127 \text { patients }(19.7 \%) \text { in the } \\
\text { placebo group }\end{array}$ \\
\hline Tocilizumab & REMDACTA [24] & $\begin{array}{l}\text { The United States } \\
\text { (41 sites), Spain (9), } \\
\text { Brazil (8), Russian } \\
\text { Federation (5) }\end{array}$ & $\begin{array}{l}\text { Patients with COVID-19 } \\
\text { requiring more than } \\
6 \mathrm{~L} / \text { min supplemental } \\
\text { oxygen to maintain } \\
\text { oxygen saturation }>93 \% \\
\text { who received } \\
\text { remdesivir (10 days) } \\
\text { and either tocilizumab } \\
\text { (1 day) or placebo } \\
\text { (control) }\end{array}$ & 649 enrolled & $\begin{array}{l}\text { Tocilizumab was given } \\
\text { intravenously as one dose }\end{array}$ & Ongoing & Ongoing \\
\hline
\end{tabular}




\section{Literature Search Strategy}

We reviewed the US FDA COVID-19 information on regulated products and consulted Micromedex ${ }^{\circledR}$ Solutions Drugs Interactions as well as Lexicomp ${ }^{\circledR}$ Drug Interactions for COVID-19 therapies. We conducted a search of PubMed for articles with the keywords "((remdesivir) or (baricitinib) or (tocilizumab) or (sarilumab)) and (COVID-19) and ((adverse event) or (toxicity) or (drug interaction))". Reference lists of all identified studies were also searched.

A total of 626 articles were collected. The clinical trials and case reports of patients with moderate-to-severe COVID-19 infection who received the targeted drugs were included in our analysis. Review articles, in vitro, and in silico studies were excluded. Articles not published in English were excluded. As shown in Figure 1, we identified 14 trials and 7 case reports on remdesivir, 4 trials and 1 case report on baricitinib, 25 trials and 9 case reports on tocilizumab, and 3 trials on sarilumab. All of the studies were conducted in America, Europe, and Asia.

\section{A search of PubMed with the keywords "((remdesivir) or (baricitinib) or (tocilizumab) or (sarilumab)) and (COVID-19) and ((adverse event) or (toxicity) or (drug interaction) $)^{\prime \prime}: 508$ articles A search of the reference lists: 118 articles}

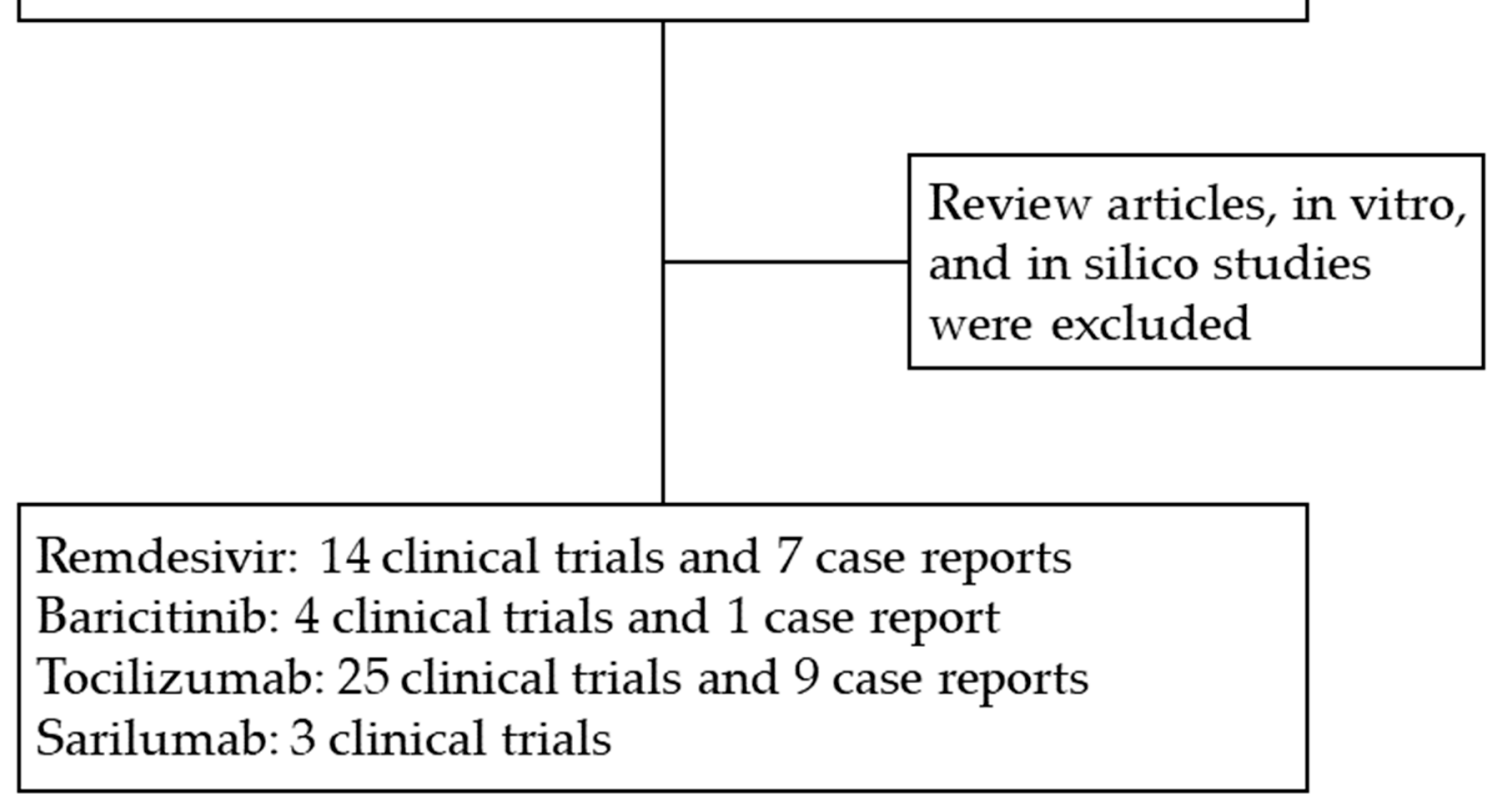

Figure 1. Study flow. Abbreviations: COVID-19, coronavirus disease 2019.

\section{Remdesivir}

\subsection{Indication}

Remdesivir in intravenous form was only approved for the treatment of COVID-19 in hospitalized patients aged $\geq 12$ years and weighing $\geq 40 \mathrm{~kg}$ [10], and was granted an EUA for hospitalized patients aged $<12$ years and weighing $\geq 3.5 \mathrm{~kg}$ by the US FDA [30]. Remdesivir is indicated in hospitalized patients requiring supplemental oxygen, invasive mechanical ventilation, or extracorporeal membrane oxygenation (ECMO) [30]. For patients who do not need respiratory support, remdesivir does not offer significant benefit at day 28, so its use is not recommended [31]. The Infectious Diseases Society of America (IDSA) and the National Institutes of Health (NIH) recommend that remdesivir should be used 
only for hospitalized patients who require non-invasive oxygen therapy [4,32], while the World Health Organization (WHO) suggests against administering remdesivir in addition to usual care [33].

\subsection{Pharmacokinetics and Mechanism of Action}

Remdesivir has moderate protein-binding capacity ( $88.0 \%$ to $93.6 \%$ bound) in human plasma, and the volume of distribution varies from 56.3 to $73.4 \mathrm{~L}$ depending on the amount of dose administered [34]. These properties make remdesivir tend to leave the plasma and enter the extravascular compartments of the body. Remdesivir, as a viral RNA-dependent RNA polymerase inhibitor, is extensively distributed in cells and metabolizes to an active nucleoside triphosphate with a half-life of 20-25 h, which competes with adenosine triphosphate for incorporation into viral RNA, causing premature chain termination and inhibition of viral replication $[34,35]$. It has been shown that $74 \%$ of remdesivir and its active metabolite are eliminated by the kidneys, and $18 \%$ are eliminated through feces. Remdesivir is not recommended in patients with severe renal insufficiency, but some studies have shown that the usual dose of remdesivir might be safe for patients with severe renal insufficiency [36], end-stage renal disease on hemodialysis [37], or kidney transplantation [38].

\subsection{Recommended Dosage}

The recommended dosage of remdesivir for COVID-19 patients is a single loading dose of $200 \mathrm{mg}$ followed by once-daily maintenance doses of $100 \mathrm{mg}$ via intravenous infusion over 30 to $120 \mathrm{~min}$. Duration is generally 5 to 10 days. In this case, a high and stable intracellular concentration of active triphosphate could be achieved to effectively inhibit SARS-CoV-2 without causing serious AEs or death [34]. However, the clinically toxic dose has not been established, and the toxicity caused by acute exposure to remdesivir can only be roughly estimated from the currently reported AEs.

\subsection{Adverse Events}

Among patients receiving remdesivir treatment, the prevalence of AEs was between $51 \%$ and $74 \%[31,39,40]$. It is unclear whether patients receiving remdesivir would have had more AEs than those receiving placebo [20,39], and it is also inconclusive as to whether patients receiving remdesivir for 10 days would have had more AEs than those receiving remdesivir for 5 days [31,40]. Grade 3 or 4 AEs occurred in $10 \%$ to $51 \%$ of patients receiving remdesivir $[17,20,31,40,41]$, but only $5 \%$ to $15 \%$ were considered to be related to remdesivir $[17,20]$. The most frequently reported AEs included alterations in liver-function studies (i.e., elevated alanine aminotransferase (ALT) and aspartate aminotransferase (AST) and hyperbilirubinemia), increased serum levels of creatinine, decreased lymphocyte count, anemia, thrombocytopenia, respiratory failure, increased blood glucose level, hypokalemia, constipation, and nausea [17,20,31,39-42]. Serious AEs developed in 5\% to $35 \%$ of patients receiving remdesivir $[17,20,31,39,40]$, the most common of which was respiratory failure $[17,20,39,40]$, but few AEs were considered to be related to remdesivir [17]. Approximately $2 \%$ to $12 \%$ of patients discontinued treatment because of AEs $[20,31,39,40]$, but whether AEs are more likely to occur in patients receiving remdesivir remains controversial $[20,39]$. The proportion of COVID-19 patients who died after receiving remdesivir ranged from $1 \%$ to $15 \%[20,31,39,41]$. The causes of death included multiple organ failure and cardiopulmonary arrest $[20,39,41,43]$, which were mainly attributed to the worsening of COVID-19 [41]. Almost all deaths were considered unrelated to remdesivir [20,31,39,43].

In addition to abnormal liver and kidney function caused by COVID-19 infection [44,45], some patients developed abnormal liver and kidney function after receiving remdesivir $[39,40]$. Remdesivir-related liver dysfunction lacks a clear pathogenesis, but gradually improves after the culprit drug is discontinued [34]. Whether remdesivir can cause renal dysfunction is unclear. Few deaths have been attributed to liver or kidney failure caused by remdesivir [43]. Another AE caused by remdesivir is atrioventricular block, leading to bradycardia and cardiac arrest, which was found in patients treated for Ebola virus 
disease [46] and COVID-19 infection [47-49]. A possible explanation is that although remdesivir triphosphate has a weak ability to inhibit mammalian DNA and RNA polymerases, it might still cause subsequent mitochondrial dysfunction, resulting in cardiotoxicity [50]. Moreover, remdesivir, as a nucleotide analog that resembles adenosine triphosphate, has partial affinity for adenosine A1 receptors, which might block the atrioventricular node and thus delay the conduction [51]. Nevertheless, studies on the cardiotoxicity caused by remdesivir are still insufficient. Remdesivir has a paucity of other severe adverse reactions, but cases of anaphylaxis have been reported [52]. Remdesivir infiltration could also result in local complications due to the low $\mathrm{pH}(\sim 4)$ of the nonbuffered remdesivir solution [53].

Remdesivir is a substrate of the cytochrome P450 (CYP) 2C8, CYP2D6, CYP3A4, organic anion transporting polypeptide 1B1 (OATP1B1), and P-glycoprotein (P-gp), and it is also an inhibitor of the CYP3A4, OATP1B1, OATP1B3, bile salt export pump (BSEP), multidrug resistance protein 4 (MRP4), and sodium and taurocholate cotransporting polypeptide (NTCP). However, based on rapid distribution, metabolism and clearance of remdesivir, the likelihood of clinically significant interactions is low [16], and only a few cases have been reported [54-56]. In contrast to cell-culture results showing that concurrent use of chloroquine or hydroxychloroquine might reduce the intracellular metabolic activation of remdesivir and lessen the antiviral activity, it was found in clinical practice that concurrent use of chloroquine and amiodarone might further inhibit the P-gp of hepatocytes that could excrete remdesivir, leading to the accumulation of remdesivir in the liver and causing the subsequent hepatotoxicity [54]. Two case reports showed that the simultaneous use of remdesivir and dexamethasone might enhance the effects of warfarin and prolong the prothrombin time [55]. Another case report showed that remdesivir might change the effectiveness of tramadol [56]. The possible role of remdesivir in drug interference has yet to be confirmed.

\section{Baricitinib}

\subsection{Indication}

Baricitinib is a crushable oral tablet that is used in combination with methotrexate to relieve the signs and symptoms of moderate to severe rheumatoid arthritis (RA) in patients who have responded inadequately to one or more disease-modifying anti-rheumatic drugs (DMARDs) [57]. In the case that remdesivir is an effective treatment for hospitalized patients with COVID-19 based on the ACTT-1 clinical trial [20], the combined use of baricitinib seems to further improve clinical outcomes based on the ACTT-2 clinical trial [17]. Baricitinib was granted an EUA by the US FDA in combination with remdesivir for the treatment of COVID-19 in hospitalized patients aged $\geq 2$ years requiring supplemental oxygen, invasive mechanical ventilation, or ECMO [11]. However, the IDSA and the NIH recommend that baricitinib should be used only for hospitalized patients who require non-invasive oxygen therapy [4,32].

\subsection{Pharmacokinetics and Mechanism of Action}

Baricitinib, as an inhibitor of Janus kinase (JAK), blocking the subtypes JAK1 and JAK2, in sequence blocks the pathway of cytokines such as interleukin-6 (IL-6) responsible for inflammatory processes. Moreover, baricitinib has been predicted to inhibit receptor-mediated endocytosis of SARS-CoV-2 by machine-learning algorithms [58]. The oral bioavailability of baricitinib is about $80 \%$. Baricitinib is $50 \%$ bound to plasma proteins, and the mean volume of distribution is $76 \mathrm{~L}$, showing distribution of baricitinib into tissues. Studies show that $75 \%$ and $20 \%$ of baricitinib are excreted in urine and feces, respectively, and approximately $6 \%$ of the dose is identified as metabolites. The half-life of elimination is $8 \mathrm{~h}$ to $12 \mathrm{~h} \mathrm{[59].} \mathrm{In} \mathrm{patients} \mathrm{with} \mathrm{any} \mathrm{level} \mathrm{of} \mathrm{renal} \mathrm{impairment} \mathrm{or} \mathrm{moderate-to-severe} \mathrm{hepatic}$ impairment, decreasing the dose or avoiding the use of baricitinib should be considered. 


\subsection{Recommended Dosage}

The recommended dosage of baricitinib for COVID-19 patients over 9 years old and younger than 9 years old are $4 \mathrm{mg}$ and $2 \mathrm{mg}$ orally once daily, respectively, for 14 days or until hospital discharge. The effect of IL-6 is maximally inhibited $1 \mathrm{~h}$ following oral administration of baricitinib, and it returns to near baseline by $24 \mathrm{~h}$. The steady-state concentration of baricitinib is achieved within 2 to 3 days. Proportional increases of the plasma concentration were observed within the range of therapeutically permitted doses. The clinically toxic dose for the COVID-19 patients has not been established, but the use of baricitinib might be associated with serious infections, thromboembolic events, and hypersensitivity reaction, based on experience using this drug to treat other diseases [60].

\subsection{Adverse Events}

It is generally believed that COVID-19 patients using baricitinib on a short-term basis are unlikely to have serious AEs. In a clinical trial of 507 adult patients with COVID-19 who received baricitinib plus remdesivir, 207 patients (40.7\%) had grade 3 or 4 AEs, of which a total of $25 \mathrm{AEs}$ were related to the treatment, which was similar to the results of the 509 patients who received remdesivir alone. Serious infection, venous thromboembolism, and pulmonary embolism occurred in $6 \%, 4 \%$, and $1 \%$ of patients treated with baricitinib plus remdesivir, respectively, which did not achieve statistically significant differences compared to those treated with remdesivir alone [17]. This might be partially explained by the fact that faster recovery could lower the risk of hospital-associated complications and may also be partly attributed to the use of thromboembolism prophylaxis. However, the potential benefits of treatment with baricitinib against potential risks should be weighed in patients with neutropenia, lymphopenia or other active infections, such as tuberculosis [11] and hepatitis B virus infection [61,62]. A higher dose of baricitinib might result in early stabilization of respiratory functions, but it could increase the risk of thromboembolism [63]. Baricitinib should be promptly discontinued if a serious hypersensitivity reaction occurs [57].

Baricitinib is a substrate of the CYP3A4, P-gp, breast cancer resistance protein (BCRP), organic anionic transporter (OAT) 3, and multidrug and toxic extrusion protein (MATE) 2-K transporters. CYP3A4 is the main metabolizing enzyme of baricitinib, but the clinical use of ketoconazole (CYP3A inhibitor) or rifampin (CYP3A inducer) has no effect on the pharmacokinetics of baricitinib [64]. The administration of probenecid (strong OAT3 inhibitor) could decrease the clearance of baricitinib, indicating that the dosage of baricitinib should be reduced in patients taking a strong OAT3 inhibitor concurrently, although diclofenac and ibuprofen (OAT3 inhibitors with less inhibition potential) did not appear to have any effect in this regard in silico [65]. Baricitinib is also an inhibitor of OAT1, OAT2, OAT3, OATP1B3, BCRP, MATE1, and MATE2-K, but it is unlikely to cause clinically meaningful changes.

\section{Tocilizumab}

\subsection{Indication}

Tocilizumab in subcutaneous or intravenous form is indicated for the treatment of chimeric antigen receptor $\mathrm{T}$ cell-induced cytokine release syndrome, active polyarticular juvenile idiopathic arthritis, systemic sclerosis-associated interstitial lung disease, moderately to severely active RA that cannot be treated with DMARDs, active systemic juvenile idiopathic arthritis, and giant cell arteritis [66]. Tocilizumab in intravenous form was granted an EUA by the US FDA for the treatment of COVID-19 in hospitalized patients aged $\geq 2$ years receiving systemic corticosteroids and requiring supplemental oxygen, non-invasive or invasive mechanical ventilation, or ECMO [12]. The IDSA, the NIH, and the WHO recommend that tocilizumab could be used in hospitalized patients with severe or critical COVID-19 [4,32,33]. 


\subsection{Pharmacokinetics and Mechanism of Action}

Tocilizumab, as an IL-6 receptor inhibitor that binds specifically to both the soluble and membrane-bound IL-6 receptors, has been shown to inhibit IL-6-mediated inflammatory processes. In COVID-19 adult patients who received intravenous tocilizumab, the mean volume of distribution was $8.75 \mathrm{~L}$, and the rate of clearance ranged from 17.6 to $35.4 \mathrm{~mL}$ per hour, increasing with the severity of the disease. The mechanism of metabolism and excretion of tocilizumab has not been clarified, but its high molecular weight of $148.0 \mathrm{kDa}$ [19,67], which is 250 times and 400 times that of remdesivir and baricitinib, respectively, indicates that tocilizumab is likely not readily excreted from the kidneys. Tocilizumab is presumed to be metabolized to smaller proteins and amino acids by proteolytic enzymes. The dosage adjustments in patients with hepatic or renal impairment has yet to be determined.

\subsection{Recommended Dosage}

The recommended dosage of tocilizumab for COVID-19 patients over $30 \mathrm{~kg}$ and under $30 \mathrm{~kg}$ comprises a single loading dose of $8 \mathrm{mg} / \mathrm{kg}$ and $12 \mathrm{mg} / \mathrm{kg}$ (maximum dose $800 \mathrm{mg}$ per infusion) over $60 \mathrm{~min}$, respectively, plus a second dose at least $8 \mathrm{~h}$ after initial infusion if clinical signs or symptoms worsen or do not improve. In adult patients with COVID-19, the estimated median peak concentrations for a single dose and two doses are $151 \mu \mathrm{g} / \mathrm{mL}$ and $290 \mu \mathrm{g} / \mathrm{mL}$, respectively, and the concentration falls below the limit of quantification by day 35 . The clinically toxic dose for COVID-19 patients has not been established.

\subsection{Adverse Events}

Among COVID-19 patients receiving tocilizumab, the prevalence of AEs was between $23 \%$ and $77 \%[22,23,68-73]$, and the prevalence of serious AEs was between $0 \%$ and $34 \%[18,22,23,68-71,73-75]$. These figures were not different compared with those of patients who received a placebo [23,68-70]. Only about $0 \%$ to $6 \%$ of patients receiving tocilizumab were considered to have causal AEs $[69,71,74,75]$. The most common AE was alteration in liver-function studies (i.e., elevated ALT and AST and hyperbilirubinemia) $[68,70-73,75-78]$, but whether AE was more likely to occur in patients receiving tocilizumab remains controversial $[77,79]$. Other common AEs include neutropenia $[70,71,73,74,77]$, which appeared to occur more frequently in patients receiving tocilizumab $[74,77]$ and might be managed with granulocyte colony-stimulating factor if necessary, and secondary bacterial infections $[18,21-23,74,77,78,80]$. There were also reports of allergic reactions $[72,81]$, sudden cardiorespiratory collapse [68,69], acute respiratory distress syndrome [70], pulmonary embolism [77], anemia [68], thrombocytopenia [68], increased serum levels of creatinine [75], and neurological adverse effects [82]. The mortality rate was between $10 \%$ and $23 \%[22,23,69,72,75]$, but almost all deaths were not related to tocilizumab [21,72].

Tocilizumab is effective in reducing the mortality of severe COVID-19 infection, but regular use of tocilizumab might be harmful due to excessive inhibition of IL-6-mediated inflammatory immune response [83]. Other infections such as tuberculosis might pose a serious threat during the treatment with tocilizumab. It remains controversial as to whether COVID-19 patients receiving tocilizumab could have fewer secondary infections due to faster recovery $[70,74,80]$. Those receiving tocilizumab might not have related complications at the early stage [84], but careful monitoring for possible late-onset infections and toxicities is warranted $[77,85,86]$. Other disease processes may harm the gastrointestinal tract, and as tocilizumab could simply block healing of the gastrointestinal tract, ulcers or bleeding may occur $[71,87]$.

Tocilizumab has few or no known serious drug interactions clinically $[16,88,89]$. The rise of IL-6 during inflammation in COVID-19 patients might inhibit the activity of CYP enzymes, thereby changing the concentration of other drugs. Tocilizumab could block the IL-6 pathway in time and normalize the metabolism, but the impact of these changes on drugs with a narrow therapeutic index remains unclear. Caution is required, especially when co-administering with myelotoxic drugs due to the potential additive toxicity [90]. 
Concomitant use of other immunosuppressive drugs should also be avoided because of the possibility of increased risk of infection.

\section{Sarilumab}

\subsection{Indication}

Sarilumab in subcutaneous form is indicated for the treatment of patients with moderately to severely active RA who have had an inadequate response or intolerance to DMARDs [91]. Sarilumab in subcutaneous or intravenous form is currently under investigational use for the treatment of COVID-19, and its efficacy and safety have not yet been determined [26,92-94]. The NIH recommends that sarilumab could be used instead of tocilizumab in hospitalized patients with severe or critical COVID-19 [4].

\subsection{Pharmacokinetics and Mechanism of Action}

Sarilumab inhibits IL-6-mediated inflammatory immune response by binding to IL-6 receptors that are both soluble and membrane-bound. Although data on the absorption, distribution, metabolism, and excretion of sarilumab are still lacking in COVID-19 patients, sarilumab has a molecular weight of approximately $150 \mathrm{kDa}[19,91]$, which is similar to tocilizumab, which implies that it might not be readily excreted from the kidneys.

\subsection{Recommended Dosage}

The dosage of sarilumab under investigation was a single loading dose of $200 \mathrm{mg}$ subcutaneously or 200 to $800 \mathrm{mg}$ intravenously.

\subsection{Adverse Events}

In the studies of COVID-19 patients receiving intravenous injection of sarilumab 200 to $400 \mathrm{mg}$, the percentage of AEs ranged from $55 \%$ to $80 \%$, the percentage of serious AEs ranged from $26 \%$ to $66 \%$, and the percentage of death ranged from $10 \%$ to $37 \%$, none of which showed a statistically significant difference in comparison with those receiving placebo $[26,94]$. However, it was found that compared with patients receiving placebo, those receiving sarilumab seemed to have higher incidences of alteration in liver function studies, neutropenia, secondary infection, and allergic reaction [26,94]. Active or latent tuberculosis was found to be another issue that should be managed before and during treatment with sarilumab [91].

\section{Conclusions}

A number of drugs with potential therapeutic efficacy have been proposed for the treatment of COVID-19 patients requiring hospitalization. However, AEs are increasingly being reported. We reviewed the pharmacokinetics, toxicity, and drug interactions of four drugs: remdesivir, baricitinib, tocilizumab, and sarilumab. The information on these drugs is summarized in Table 3. The most common AE among these drugs was alteration in liver-function studies, but serious AEs have rarely been attributed to them. Remdesivir might cause cardiotoxicity such as atrioventricular block, so close cardiac monitoring is essential. Patients receiving baricitinib might have a higher risk of thromboembolism, and thus prophylaxis should be considered. When IL-6-mediated inflammatory processes are inhibited by biological agents such as baricitinib, tocilizumab, and sarilumab, immune dysregulation seems to be another important issue, and thus the potential benefits of treatment should be evaluated against the possible increased risks of secondary infection. Although AEs could resolve spontaneously in most patients after discontinuing the culprit drug, greater vigilance is warranted for patients with high susceptibility in order to prevent irreversible damage. Further study is needed to explore the pathogenic mechanisms involved and to determine the relevant risk factors so that novel treatment strategies can be developed. 
Table 3. The summary of available drugs for the treatment of moderate-to-severe COVID-19.

\begin{tabular}{|c|c|c|c|c|c|}
\hline Drugs & Possible Mechanisms & $\begin{array}{l}\text { Indications for the Treatment of } \\
\text { COVID-19 }\end{array}$ & $\begin{array}{c}\text { Routes of } \\
\text { Administration }\end{array}$ & Recommended Dosage & Related Adverse Events \\
\hline Remdesivir & $\begin{array}{l}\text { Nucleotide analogue; inhibit } \\
\text { viral nucleotide synthesis to } \\
\text { stop viral replication. }\end{array}$ & $\begin{array}{l}\text { Approved by the US FDA in } \\
\text { hospitalized patients aged } \geq 12 \text { years } \\
\text { and weighing } \geq 40 \mathrm{~kg} \text {; granted an EUA } \\
\text { by the US FDA in hospitalized patients } \\
\text { aged }<12 \text { years and weighing } \geq 3.5 \mathrm{~kg} \text {. }\end{array}$ & Intravenous. & $\begin{array}{l}\text { A single loading dose of } 200 \mathrm{mg} \\
\text { followed by once-daily maintenance } \\
\text { doses of } 100 \mathrm{mg} \text { for } 5 \text { to } 10 \text { days or } \\
\text { until hospital discharge. }\end{array}$ & $\begin{array}{l}\text { Alterations in liver function } \\
\text { studies, increased serum } \\
\text { levels of creatinine, } \\
\text { atrioventricular block, } \\
\text { and anaphylaxis. }\end{array}$ \\
\hline Baricitinib & $\begin{array}{l}\text { JAK inhibitor; blocks } \\
\text { JAK-STAT signaling pathway } \\
\text { and inflammatory response. }\end{array}$ & $\begin{array}{l}\text { Granted an EUA by the US FDA in } \\
\text { combination with remdesivir in } \\
\text { hospitalized patients aged } \geq 2 \text { years } \\
\text { requiring supplemental oxygen, invasive } \\
\text { mechanical ventilation, or extracorporeal } \\
\text { membrane oxygenation. }\end{array}$ & Oral. & $\begin{array}{l}4 \text { mg in patients aged over } 9 \text { years } \\
\text { and } 2 \text { mg aged under } 9 \text { years once } \\
\text { daily for } 14 \text { days or until } \\
\text { hospital discharge. }\end{array}$ & $\begin{array}{l}\text { Thromboembolism, } \\
\text { secondary infections, and } \\
\text { hypersensitivity reaction. }\end{array}$ \\
\hline Tocilizumab & $\begin{array}{l}\text { IL-6 receptor antagonist; } \\
\text { inhibit IL-6 signaling } \\
\text { pathway. }\end{array}$ & $\begin{array}{l}\text { Granted an EUA by the US FDA in } \\
\text { hospitalized patients aged } \geq 2 \text { years } \\
\text { receiving systemic corticosteroids and } \\
\text { requiring supplemental oxygen, } \\
\text { non-invasive or invasive mechanical } \\
\text { ventilation, or extracorporeal } \\
\text { membrane oxygenation. }\end{array}$ & Intravenous. & $\begin{array}{l}\text { First dose: a single loading dose of } \\
8 \mathrm{mg} / \mathrm{kg} \text { in patients over } 30 \mathrm{~kg} \text {, and } \\
12 \mathrm{mg} / \mathrm{kg} \text { in patients under } 30 \mathrm{~kg} \\
\text { (max. } 800 \mathrm{mg} \text { ). } \\
\text { Second dose: another single loading } \\
\text { dose at least } 8 \mathrm{~h} \text { later if } \\
\text { not improved. }\end{array}$ & $\begin{array}{l}\text { Alteration in liver function } \\
\text { studies, neutropenia, } \\
\text { secondary infections, and } \\
\text { allergic reactions. }\end{array}$ \\
\hline Sarilumab & $\begin{array}{l}\text { IL-6 receptor antagonist; } \\
\text { inhibit IL-6 signaling } \\
\text { pathway. }\end{array}$ & Under investigational use. & $\begin{array}{l}\text { Subcutaneous or } \\
\text { intravenous. }\end{array}$ & $\begin{array}{l}\text { A single loading dose of } 200 \mathrm{mg} \\
\text { subcutaneously or } 200 \text { to } 800 \mathrm{mg} \\
\text { intravenously. }\end{array}$ & $\begin{array}{l}\text { Alteration in liver function } \\
\text { studies, neutropenia, } \\
\text { secondary infection, and } \\
\text { allergic reaction. }\end{array}$ \\
\hline
\end{tabular}

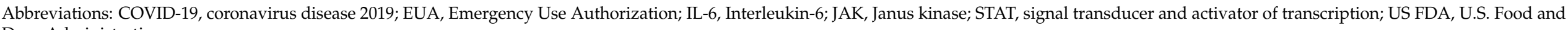

Drug Administration. 
Author Contributions: Conceptualization, J.-Y.H. and P.-Y.L.; formal analysis, J.-Y.H.; writingoriginal draft preparation, J.-Y.H.; writing-review and editing, K.-L.L. and Y.-C.M.; supervision, P.-Y.L. All authors have read and agreed to the published version of the manuscript.

Funding: This research received no external funding.

Institutional Review Board Statement: Not applicable.

Informed Consent Statement: Not applicable.

Data Availability Statement: Data sharing not applicable.

Conflicts of Interest: The authors declare no conflict of interest.

\section{References}

1. World Health Organization. WHO Coronavirus (COVID-19) Dashboard. Available online: https://covid19.who.int/ (accessed on 21 September 2021).

2. Roviello, V.; Roviello, G.N. Less COVID-19 deaths in southern and insular Italy explained by forest bathing, Mediterranean environment, and antiviral plant volatile organic compounds. Environ. Chem. Lett. 2021, 1-11. [CrossRef]

3. Costanzo, M.; De Giglio, M.A.R.; Roviello, G.N. Anti-Coronavirus Vaccines: Past Investigations on SARS-CoV-1 and MERS$\mathrm{CoV}$, the Approved Vaccines from BioNTech/Pfizer, Moderna, Oxford/AstraZeneca and others under Development Against SARS-CoV-2 Infection. Curr. Med. Chem. 2021. [CrossRef] [PubMed]

4. National Institutes of Health (NIH) COVID-19 Treatment Guidelines Panel. Coronavirus Disease 2019 (COVID-19) Treatment Guidelines. National Institutes of Health. Available online: https:/ / files.covid19treatmentguidelines.nih.gov/guidelines/covid1 9treatmentguidelines.pdf (accessed on 17 September 2021).

5. Regeneron Pharmaceuticals Inc. Fact Sheet for Healthcare Providers: Emergency Use Authorization (EUA) of Casirivimab and Imdevimab. Available online: https:/ / www.fda.gov/media/145611/download (accessed on 17 September 2021).

6. Eli Lilly and Company. Fact Sheet for Healthcare Providers: Emergency Use Authorization (EUA) of Bamlanivimab and Etesevimab. Available online: https:/ / www.fda.gov/media/145802/download (accessed on 17 September 2021).

7. GlaxoSmithKline LLC. Fact Sheet for Healthcare Providers: Emergency Use Authorization (EUA) of Sotrovimab. Available online: https: / / www.fda.gov/media/149534/download (accessed on 17 September 2021).

8. The RECOVERY Collaborative Group. Dexamethasone in Hospitalized Patients with COVID-19. N. Engl. J. Med. 2021, 384, 693-704. [CrossRef]

9. US Food \& Drug Administration (FDA). Clinical Memorandum: COVID-19 Convalescent Plasma. Available online: https: / / www.fda.gov/media/141480/download (accessed on 1 August 2021).

10. Gilead Sciences Inc. Full Prescribing Information: Remdesivir, for Intravenous Use. Available online: https://www.accessdata. fda.gov/drugsatfda_docs/label/2020/214787Orig1s000lbl.pdf (accessed on 1 August 2021).

11. Eli Lilly and Company. Fact Sheet for Healthcare Providers: Emergency Use Authorization (EUA) of Baricitinib. Available online: https:/ / www.fda.gov / media/143823/download (accessed on 1 August 2021).

12. Genentech Inc. Fact Sheet for Healthcare Providers: Emergency Use Authorization (EUA) of Tocilizumab. Available online: https: / / www.fda.gov/media/150321/download (accessed on 1 August 2021).

13. US Food \& Drug Administration (FDA). Memorandum Explaining Basis for Revocation of Emergency Use Authorization for Emergency Use of Chloroquine Phosphate and Hydroxychloroquine Sulfate. Available online: https://www.fda.gov/media/13 8945 / download (accessed on 1 August 2021).

14. Cao, B.; Wang, Y.; Wen, D.; Liu, W.; Wang, J.; Fan, G.; Ruan, L.; Song, B.; Cai, Y.; Wei, M.; et al. A Trial of Lopinavir-Ritonavir in Adults Hospitalized with Severe COVID-19. N. Engl. J. Med. 2020, 382, 1787-1799. [CrossRef] [PubMed]

15. Horby, P.W.; Mafham, M.; Bell, J.L.; Linsell, L.; Staplin, N.; Emberson, J.; Palfreeman, A.; Raw, J.; Elmahi, E.; Prudon, B.; et al. Lopinavir-ritonavir in patients admitted to hospital with COVID-19 (RECOVERY): A randomised, controlled, open-label, platform trial. Lancet 2020, 396, 1345-1352. [CrossRef]

16. Cattaneo, D.; Pasina, L.; Maggioni, A.P.; Giacomelli, A.; Oreni, L.; Covizzi, A.; Bradanini, L.; Schiuma, M.; Antinori, S.; Ridolfo, A.; et al. Drug-Drug Interactions and Prescription Appropriateness in Patients with COVID-19: A Retrospective Analysis from a Reference Hospital in Northern Italy. Drugs Aging 2020, 37, 925-933. [CrossRef] [PubMed]

17. Kalil, A.C.; Patterson, T.F.; Mehta, A.K.; Tomashek, K.M.; Wolfe, C.R.; Ghazaryan, V.; Marconi, V.C.; Ruiz-Palacios, G.M.; Hsieh, L.; Kline, S.; et al. Baricitinib plus Remdesivir for Hospitalized Adults with COVID-19. N. Engl. J. Med. 2021, 384, 795-807. [CrossRef]

18. The REMAP-CAP Investigators. Interleukin-6 Receptor Antagonists in Critically Ill Patients with COVID-19. N. Engl. J. Med. 2021, 384, 1491-1502. [CrossRef] [PubMed]

19. Wishart, D.S.; Feunang, Y.D.; Guo, A.C.; Lo, E.J.; Marcu, A.; Grant, J.R.; Sajed, T.; Johnson, D.; Li, C.; Sayeeda, Z.; et al. DrugBank 5.0: A major update to the DrugBank database for 2018. Nucleic Acids Res. 2017, 46, D1074-D1082. [CrossRef]

20. Beigel, J.H.; Tomashek, K.M.; Dodd, L.E.; Mehta, A.K.; Zingman, B.S.; Kalil, A.C.; Hohmann, E.; Chu, H.Y.; Luetkemeyer, A.; Kline, S.; et al. Remdesivir for the Treatment of COVID-19-Final Report. N. Engl. J. Med. 2020, 383. [CrossRef] 
21. Abani, O.; Abbas, A.; Abbas, F.; Abbas, M.; Abbasi, S.; Abbass, H.; Abbott, A.; Abdallah, N.; Abdelaziz, A.; Abdelfattah, M.; et al. Tocilizumab in patients admitted to hospital with COVID-19 (RECOVERY): A randomised, controlled, open-label, platform trial. Lancet 2021, 397, 1637-1645. [CrossRef]

22. Salama, C.; Han, J.; Yau, L.; Reiss, W.G.; Kramer, B.; Neidhart, J.D.; Criner, G.J.; Kaplan-Lewis, E.; Baden, R.; Pandit, L.; et al. Tocilizumab in Patients Hospitalized with COVID-19 Pneumonia. N. Engl. J. Med. 2021, 384, 20-30. [CrossRef]

23. Rosas, I.O.; Bräu, N.; Waters, M.; Go, R.C.; Hunter, B.D.; Bhagani, S.; Skiest, D.; Aziz, M.S.; Cooper, N.; Douglas, I.S.; et al. Tocilizumab in Hospitalized Patients with Severe COVID-19 Pneumonia. N. Engl. J. Med. 2021, 384, 1503-1516. [CrossRef] [PubMed]

24. Roche, H.-L.; Sciences, G. A Study to Evaluate the Efficacy and Safety of Remdesivir Plus Tocilizumab Compared With Remdesivir Plus Placebo in Hospitalized Participants With Severe COVID-19 Pneumonia. Available online: https:/ ClinicalTrials.gov/show / NCT04409262 (accessed on 1 August 2021).

25. Della-Torre, E.; Lanzillotta, M.; Campochiaro, C.; Cavalli, G.; De Luca, G.; Tomelleri, A.; Boffini, N.; De Lorenzo, R.; Ruggeri, A.; Rovere-Querini, P.; et al. Respiratory Impairment Predicts Response to IL-1 and IL-6 Blockade in COVID-19 Patients With Severe Pneumonia and Hyper-Inflammation. Front. Immunol. 2021, 12, 675678. [CrossRef] [PubMed]

26. Lescure, F.-X.; Honda, H.; Fowler, R.A.; Lazar, J.S.; Shi, G.; Wung, P.; Patel, N.; Hagino, O.; Bazzalo, I.J.; Casas, M.M.; et al. Sarilumab in patients admitted to hospital with severe or critical COVID-19: A randomised, double-blind, placebo-controlled, phase 3 trial. Lancet Respir. Med. 2021, 9, 522-532. [CrossRef]

27. Garcia-Vicuña, R.; Abad-Santos, F.; González-Alvaro, I.; Ramos-Lima, F.; Sanz, J.S. Subcutaneous Sarilumab in hospitalised patients with moderate-severe COVID-19 infection compared to the standard of care (SARCOVID): A structured summary of a study protocol for a randomised controlled trial. Trials 2020, 21, 772. [CrossRef] [PubMed]

28. Boyapati, A.; Wipperman, M.F.; Ehmann, P.J.; Hamon, S.; Lederer, D.J.; Waldron, A.; Flanagan, J.J.; Karayusuf, E.; Bhore, R.; Nivens, M.C.; et al. Baseline SARS-CoV-2 Viral Load is Associated With COVID-19 Disease Severity and Clinical Outcomes: Post-Hoc Analyses of a Phase 2/3 Trial. J. Infect. Dis. 2021. [CrossRef]

29. López, R.L.; Fernández, S.C.; Pérez, L.L.; Palacios, A.R.; Fernández-Roldán, M.C.; Alonso, E.A.; Camacho, I.P.; Rodriguez-Baño, J.; Merchante, N.; Olalla, J.; et al. Efficacy and safety of early treatment with sarilumab in hospitalised adults with COVID-19 presenting cytokine release syndrome (SARICOR STUDY): Protocol of a phase II, open-label, randomised, multicentre, controlled clinical trial. BMJ Open 2020, 10, e039951. [CrossRef]

30. Gilead Sciences Inc. Fact Sheet for Healthcare Providers: Emergency Use Authorization (EUA) of Remdesivir for Hospitalized Pediatric Patients Weighing $3.5 \mathrm{~kg}$ to Less than $40 \mathrm{~kg}$ or Hospitalized Pediatric Patients Less than 12 Years of Age Weighing at least $3.5 \mathrm{~kg}$. Available online: https:/ / www.fda.gov/media/137566/download (accessed on 1 August 2021).

31. Spinner, C.D.; Gottlieb, R.L.; Criner, G.J.; López, J.R.A.; Cattelan, A.M.; Viladomiu, A.S.; Ogbuagu, O.; Malhotra, P.; Mullane, K.M.; Castagna, A.; et al. Effect of Remdesivir vs. Standard Care on Clinical Status at 11 Days in Patients with Moderate COVID-19: A Randomized Clinical Trial. JAMA 2020, 324, 1048-1057. [CrossRef]

32. Bhimraj, A.; Morgan, R.L.; Shumaker, A.H.; Lavergne, V.; Baden, L.; Cheng, V.C.; Edwards, K.M.; Gandhi, R.; Gallagher, J.; Muller, W.J.; et al. Infectious Diseases Society of America Guidelines on the Treatment and Management of Patients with COVID-19. Infectious Diseases Society of America 2021; Version 5.1.2. Available online: https:/ /www.idsociety.org/practice-guideline/ covid-19-Guideline-Treatment-and-Management/ (accessed on 17 September 2021).

33. World Health Organization. Therapeutics and COVID-19: Living Guideline. Available online: https://apps.who.int/iris/rest/ bitstreams /1354702/retrieve (accessed on 17 September 2021).

34. Humeniuk, R.; Mathias, A.; Cao, H.; Osinusi, A.; Shen, G.; Chng, E.; Ling, J.; Vu, A.; German, P. Safety, Tolerability, and Pharmacokinetics of Remdesivir, An Antiviral for Treatment of COVID-19, in Healthy Subjects. Clin. Transl. Sci. 2020, 13, 896-906. [CrossRef]

35. Borbone, N.; Piccialli, G.; Roviello, G.N.; Oliviero, G. Nucleoside Analogs and Nucleoside Precursors as Drugs in the Fight against SARS-CoV-2 and Other Coronaviruses. Molecules 2021, 26, 986. [CrossRef] [PubMed]

36. Pettit, N.N.; Pisano, J.; Nguyen, C.T.; Lew, A.K.; Hazra, A.; Sherer, R.; Mullane, K.M. Remdesivir Use in the Setting of Severe Renal Impairment: A Theoretical Concern or Real Risk? Clin. Infect. Dis. 2020. [CrossRef] [PubMed]

37. Sörgel, F.; Malin, J.J.; Hagmann, H.; Kinzig, M.; Bilal, M.; Eichenauer, D.A.; Scherf-Clavel, O.; Simonis, A.; El Tabei, L.; Fuhr, U.; et al. Pharmacokinetics of remdesivir in a COVID-19 patient with end-stage renal disease on intermittent haemodialysis. $J$. Antimicrob. Chemother. 2020, 76, 825-827. [CrossRef]

38. Buxeda, A.; Arias-Cabrales, C.; Pérez-Sáez, M.J.; Cacho, J.; Pelegrin, S.C.; Melilli, E.; Aladrén, M.J.; Galeano, C.; Lorenzo, I.; Mazuecos, A.; et al. Use and Safety of Remdesivir in Kidney Transplant Recipients With COVID-19. Kidney Int. Rep. 2021, 6, 2305-2315. [CrossRef] [PubMed]

39. Wang, Y.; Zhang, D.; Du, G.; Du, R.; Zhao, J.; Jin, Y.; Fu, S.; Gao, L.; Cheng, Z.; Lu, Q.; et al. Remdesivir in adults with severe COVID-19: A randomised, double-blind, placebo-controlled, multicentre trial. Lancet 2020, 395, 1569-1578. [CrossRef]

40. Goldman, J.D.; Lye, D.C.B.; Hui, D.S.; Marks, K.M.; Bruno, R.; Montejano, R.; Spinner, C.D.; Galli, M.; Ahn, M.-Y.; Nahass, R.G.; et al. Remdesivir for 5 or 10 Days in Patients with Severe COVID-19. N. Engl. J. Med. 2020, 383. [CrossRef] [PubMed]

41. ACTIV-3/TICO LY-CoV555 Study Group. A Neutralizing Monoclonal Antibody for Hospitalized Patients with COVID-19. N. Engl. J. Med. 2021, 384, 905-914. [CrossRef] 
42. Antinori, S.; Cossu, M.V.; Ridolfo, A.L.; Rech, R.; Bonazzetti, C.; Pagani, G.; Gubertini, G.; Coen, M.; Magni, C.; Castelli, A.; et al. Compassionate remdesivir treatment of severe COVID-19 pneumonia in intensive care unit (ICU) and Non-ICU patients: Clinical outcome and differences in post-treatment hospitalisation status. Pharmacol. Res. 2020, 158, 104899. [CrossRef] [PubMed]

43. WHO Solidarity Trial Consortium. Repurposed Antiviral Drugs for COVID-19-Interim WHO Solidarity Trial Results. N. Engl. J. Med. 2021, 384, 497-511. [CrossRef]

44. Bertolini, A.; Van De Peppel, I.P.; Bodewes, F.A.; Moshage, H.; Fantin, A.; Farinati, F.; Fiorotto, R.; Jonker, J.W.; Strazzabosco, M.; Verkade, H.J.; et al. Abnormal Liver Function Tests in Patients With COVID-19: Relevance and Potential Pathogenesis. Hepatology 2020, 72, 1864-1872. [CrossRef]

45. Benedetti, C.; Waldman, M.; Zaza, G.; Riella, L.V.; Cravedi, P. COVID-19 and the Kidneys: An Update. Front. Med. 2020, 7, 423. [CrossRef]

46. Mulangu, S.; Dodd, L.E.; Davey, R.T.; Mbaya, O.T.; Proschan, M.; Mukadi, D.; Manzo, M.L.; Nzolo, D.; Oloma, A.T.; Ibanda, A.; et al. A Randomized, Controlled Trial of Ebola Virus Disease Therapeutics. N. Engl. J. Med. 2019, 381, 2293-2303. [CrossRef] [PubMed]

47. Gupta, A.K.; Parker, B.M.; Priyadarshi, V.; Parker, J. Cardiac Adverse Events with Remdesivir in COVID-19 Infection. Cureus 2020, 12, e11132. [CrossRef] [PubMed]

48. Gubitosa, J.C.; Kakar, P.; Gerula, C.; Nossa, H.; Finkel, D.; Wong, K.; Khatri, M.; Ali, H. Marked Sinus Bradycardia Associated With Remdesivir in COVID-19. JACC Case Rep. 2020, 2, 2260-2264. [CrossRef]

49. Selvaraj, V.; Bavishi, C.; Patel, S.; Dapaah-Afriyie, K. Complete heart block associated with Remdesivir in COVID-19: A case report. Eur. Hear. J. Case Rep. 2021, 5, ytab200. [CrossRef] [PubMed]

50. Varga, Z.V.; Ferdinandy, P.; Liaudet, L.; Pacher, P. Drug-induced mitochondrial dysfunction and cardiotoxicity. Am. J. Physiol. Circ. Physiol. 2015, 309, H1453-H1467. [CrossRef] [PubMed]

51. Zipes, D.P.; Libby, P.; Bonow, R.O.; Mann, D.L.; Tomaselli, G.F.; Braunwald, E. Braunwald's Heart Disease: A Textbook of Cardiovascular Medicine; Elsevier/Saunders: Philadelphia, PA, USA, 2019.

52. Hopkins, B.J.; Prokesch, B.C. Anaphylaxis Due to Remdesivir. Antimicrob. Agents Chemother. 2021, 65, e00233-21. [CrossRef]

53. Van Merendonk, L.N.; Leeuwerik, A.F.; Brok, M.W.J.D.; Hekking, P.-P.W.; Korevaar, D.A.; Jacobs, C.J.; Bet, P.M. Peripheral infiltration of remdesivir in 3 patients with COVID-19: Case series and discussion. Am. J. Health Pharm. 2021. [CrossRef] [PubMed]

54. Leegwater, E.; Strik, A.; Wilms, E.B.; Bosma, L.B.E.; Burger, D.M.; Ottens, T.H.; van Nieuwkoop, C. Drug-induced Liver Injury in a Patient With Coronavirus Disease 2019: Potential Interaction of Remdesivir With P-Glycoprotein Inhibitors. Clin. Infect. Dis. 2020, 72, 1256-1258. [CrossRef]

55. Landayan, R.P.; Saint-Felix, S.; Williams, A. Probable Interaction Between Warfarin and the Combination of Remdesivir With Dexamethasone for Coronavirus Disease 2019 (COVID-19) Treatment: A 2 Case Report. J. Pharm. Pract. 2021. [CrossRef] [PubMed]

56. Teoli, D.; Thompson, V.; Wright, J.; Ho, I.; Vlaminck, B.; Miller, G.; Feely, M. Acute Pain Crisis Caused by Tramadol Remdesivir Drug-Drug Interaction. J. Palliat. Med. 2021. [CrossRef] [PubMed]

57. Eli Lilly Canada Inc. Product Monograph Including Patient Medication Information: OLUMIANT ${ }^{\circledR}$, Baricitinib, Oral Tablets. Available online: http:/ / pi.lilly.com/ca/olumiant-ca-pm.pdf (accessed on 1 August 2021).

58. Richardson, P.; Griffin, I.; Tucker, C.; Smith, D.; Oechsle, O.; Phelan, A.; Rawling, M.; Savory, E.; Stebbing, J. Baricitinib as potential treatment for 2019-nCoV acute respiratory disease. Lancet 2020, 395, e30-e31. [CrossRef]

59. Shi, J.G.; Chen, X.; Lee, F.; Emm, T.; Scherle, P.A.; Lo, Y.; Punwani, N.; Williams, W.V.; Yeleswaram, S. The pharmacokinetics, pharmacodynamics, and safety of baricitinib, an oral JAK $1 / 2$ inhibitor, in healthy volunteers. J. Clin. Pharmacol. 2014, 54, 1354-1361. [CrossRef]

60. Peng, L.; Xiao, K.; Ottaviani, S.; Stebbing, J.; Wang, Y.-J. A real-world disproportionality analysis of FDA Adverse Event Reporting System (FAERS) events for baricitinib. Expert Opin. Drug Saf. 2020, 19, 1505-1511. [CrossRef] [PubMed]

61. Guan, W.-J.; Liang, W.-H.; Zhao, Y.; Liang, H.-R.; Chen, Z.-S.; Li, Y.-M.; Liu, X.-Q.; Chen, R.-C.; Tang, C.-L.; Wang, T.; et al. Comorbidity and its impact on 1590 patients with COVID-19 in China: A nationwide analysis. Eur. Respir. J. 2020, 55, 2000547. [CrossRef]

62. Guan, W.-J.; Ni, Z.-Y.; Hu, Y.; Liang, W.-H.; Ou, C.-Q.; He, J.-X.; Liu, L.; Shan, H.; Lei, C.-L.; Hui, D.S.; et al. Clinical Characteristics of Coronavirus Disease 2019 in China. N. Engl. J. Med. 2020, 382, 1708-1720. [CrossRef] [PubMed]

63. Hasan, J.; Rabbani, R.; Anam, A.M.; Huq, S.M.R.; Polash, M.M.I.; Nessa, S.S.T.; Bachar, S.C. Impact of high dose of baricitinib in severe COVID-19 pneumonia: A prospective cohort study in Bangladesh. BMC Infect. Dis. 2021, 21, 427. [CrossRef] [PubMed]

64. Markham, A. Baricitinib: First Global Approval. Drugs 2017, 77, 697-704. [CrossRef]

65. Posada, M.M.; Cannady, E.A.; Payne, C.D.; Zhang, X.; Bacon, J.A.; Pak, Y.A.; Higgins, J.W.; Shahri, N.; Hall, S.D.; Hillgren, K.M. Prediction of Transporter-Mediated Drug-Drug Interactions for Baricitinib. Clin. Transl. Sci. 2017, 10, 509-519. [CrossRef]

66. Genentech, I. Full Prescribing Information: ACTEMRA ${ }^{\circledR}$, Tocilizumab, Injection, for Intravenous or Subcutaneous Use. Available online: https://www.gene.com/download/pdf/actemra_prescribing.pdf (accessed on 15 September 2021).

67. Abou-Auda, H.S.; Sakr, W. Tocilizumab: A new anti-rheumatic drug. Saudi Pharm. J. 2010, 18, 257-259. [CrossRef] 
68. Veiga, V.C.; Prats, J.A.G.G.; Farias, D.L.C.; Rosa, R.G.; Dourado, L.K.; Zampieri, F.G.; Machado, F.R.; Lopes, R.D.; Berwanger, O.; Azevedo, L.C.P.; et al. Effect of tocilizumab on clinical outcomes at 15 days in patients with severe or critical coronavirus disease 2019: Randomised controlled trial. BMJ 2021, 372, n84. [CrossRef] [PubMed]

69. Soin, A.S.; Kumar, K.; Choudhary, N.S.; Sharma, P.; Mehta, Y.; Kataria, S.; Govil, D.; Deswal, V.; Chaudhry, D.; Singh, P.K.; et al. Tocilizumab plus standard care versus standard care in patients in India with moderate to severe COVID-19-associated cytokine release syndrome (COVINTOC): An open-label, multicentre, randomised, controlled, phase 3 trial. Lancet Respir. Med. 2021, 9 , 511-521. [CrossRef]

70. Hermine, O.; Mariette, X.; Tharaux, P.-L.; Resche-Rigon, M.; Porcher, R.; Ravaud, P.; Bureau, S.; Dougados, M.; Tibi, A.; CORIMUNO-19 Collaborative Group; et al. Effect of Tocilizumab vs. Usual Care in Adults Hospitalized With COVID-19 and Moderate or Severe Pneumonia. JAMA Intern. Med. 2021, 181, 32-40. [CrossRef] [PubMed]

71. Salvarani, C.; Dolci, G.; Massari, M.; Merlo, D.F.; Cavuto, S.; Savoldi, L.; Bruzzi, P.; Boni, F.; Braglia, L.; Turrà, C.; et al. Effect of Tocilizumab vs. Standard Care on Clinical Worsening in Patients Hospitalized With COVID-19 Pneumonia: A Randomized Clinical Trial. JAMA Intern. Med. 2021, 181, 24-31. [CrossRef]

72. Perrone, F.; Piccirillo, M.C.; Ascierto, P.A.; Salvarani, C.; Parrella, R.; Marata, A.M.; Popoli, P.; Ferraris, L.; Marrocco-Trischitta, M.M.; Ripamonti, D.; et al. Tocilizumab for patients with COVID-19 pneumonia. The single-arm TOCIVID-19 prospective trial. J. Transl. Med. 2020, 18, 1-11. [CrossRef] [PubMed]

73. Wang, D.; Fu, B.; Peng, Z.; Yang, D.; Han, M.; Li, M.; Yang, Y.; Yang, T.; Sun, L.; Li, W.; et al. Tocilizumab in patients with moderate or severe COVID-19: A randomized, controlled, open-label, multicenter trial. Front. Med. 2021, 15, 486-494. [CrossRef] [PubMed]

74. Stone, J.H.; Frigault, M.J.; Serling-Boyd, N.J.; Fernandes, A.D.; Harvey, L.; Foulkes, A.S.; Horick, N.K.; Healy, B.C.; Shah, R.; Bensaci, A.M.; et al. Efficacy of Tocilizumab in Patients Hospitalized with COVID-19. N. Engl. J. Med. 2020, 383, $2333-2344$. [CrossRef]

75. Malekzadeh, R.; Abedini, A.; Mohsenpour, B.; Sharifipour, E.; Ghasemian, R.; Javad-Mousavi, S.A.; Khodashahi, R.; Darban, M.; Kalantari, S.; Abdollahi, N.; et al. Subcutaneous tocilizumab in adults with severe and critical COVID-19: A prospective open-label uncontrolled multicenter trial. Int. Immunopharmacol. 2020, 89, 107102. [CrossRef]

76. Zhao, H.; Zhu, Q.; Zhang, C.; Li, J.; Wei, M.; Qin, Y.; Chen, G.; Wang, K.; Yu, J.; Wu, Z.; et al. Tocilizumab combined with favipiravir in the treatment of COVID-19: A multicenter trial in a small sample size. Biomed. Pharmacother. 2020, 133. [CrossRef]

77. Roumier, M.; Paule, R.; Vallée, A.; Rohmer, J.; Ballester, M.; Brun, A.-L.; Cerf, C.; Chabi, M.-L.; Chinet, T.; Colombier, M.-A.; et al. Tocilizumab for Severe Worsening COVID-19 Pneumonia: A Propensity Score Analysis. J. Clin. Immunol. 2020, 41, 303-314. [CrossRef] [PubMed]

78. West, T.A.; Malik, S.; Nalpantidis, A.; Tran, T.; Cannon, C.; Bhonagiri, D.; Chan, K.; Cheong, E.; Cheong, J.W.S.; Cheung, W.; et al. Tocilizumab for severe COVID-19 pneumonia: Case series of 5 Australian patients. Int. J. Rheum. Dis. 2020, 23, 1030-1039. [CrossRef]

79. Taramasso, L.; Vena, A.; Bovis, F.; Portunato, F.; Mora, S.; Dentone, C.; Delfino, E.; Mikulska, M.; Giacobbe, D.R.; De Maria, A.; et al. Higher Mortality and Intensive Care Unit Admissions in COVID-19 Patients with Liver Enzyme Elevations. Microorganisms 2020, 8, 2010. [CrossRef] [PubMed]

80. Mehta, M.; Purpura, L.J.; McConville, T.H.; Neidell, M.J.; Anderson, M.R.; Bernstein, E.J.; Dietz, D.E.; Laracy, J.; Gunaratne, S.H.; Miller, E.H.; et al. What about tocilizumab? A retrospective study from a NYC Hospital during the COVID-19 outbreak. PLoS ONE 2021, 16, e0249349. [CrossRef] [PubMed]

81. Sernicola, A.; Carnicelli, G.; Di Fraia, M.; Chello, C.; Furlan, C.; Muharremi, R.; Paolino, G.; Grieco, T. 'Toxic erythema' and eosinophilia associated with tocilizumab therapy in a COVID-19 patient. J. Eur. Acad. Dermatol. Venereol. 2020, 34, e368-e370. [CrossRef] [PubMed]

82. Dastan, F.; Saffaei, A.; Haseli, S.; Marjani, M.; Moniri, A.; Abtahian, Z.; Abedini, A.; Kiani, A.; Seifi, S.; Jammati, H.; et al. Promising effects of tocilizumab in COVID-19: A non-controlled, prospective clinical trial. Int. Immunopharmacol. 2020, 88, 106869. [CrossRef] [PubMed]

83. Bruzzese, V.; Lazzarino, A.I. The paradoxical effect of IL-6 and implications for the use of Tocilizumab in COVID-19 patients. Med. Hypotheses 2020, 144, 110284. [CrossRef] [PubMed]

84. Galván-Román, J.M.; Rodríguez-García, S.C.; Roy-Vallejo, E.; Marcos-Jiménez, A.; Sánchez-Alonso, S.; Fernández-Díaz, C.; Alcaraz-Serna, A.; Mateu-Albero, T.; Rodríguez-Cortes, P.; Sánchez-Cerrillo, I.; et al. IL-6 serum levels predict severity and response to tocilizumab in COVID-19: An observational study. J. Allergy Clin. Immunol. 2020, 147, 72-80.e8. [CrossRef] [PubMed]

85. Pettit, N.N.; Nguyen, C.T.; Mutlu, G.M.; Wu, D.; Kimmig, L.; Pitrak, D.; Pursell, K. Late onset infectious complications and safety of tocilizumab in the management of COVID-19. J. Med. Virol. 2020, 93, 1459-1464. [CrossRef]

86. Podlasin, R.B.; Kowalska, J.D.; Pihowicz, A.; Wojtycha-Kwaśnica, B.; Thompson, M.; Dyda, T.; Czeszko-Paprocka, H.; Horban, A. How to follow-up a patient who received tocilizumab in severe COVID-19: A case report. Eur. J. Med. Res. 2020, 25, 1-6. [CrossRef]

87. Bruce-Hickman, D.; Sajeed, S.M.; Pang, Y.H.; Seow, C.S.; Chen, W.; Kansal, M.G. Bowel ulceration following tocilizumab administration in a COVID-19 patient. BMJ Open Gastroenterol. 2020, 7, e000484. [CrossRef]

88. Martínez-López-De-Castro, N.; Samartín-Ucha, M.; Paradela-Carreiro, A.; Pérez-Landeiro, A.; Inaraja-Bobo, M.T.; Álvarez-Payero, M.; Castro-Núñez, I.; García-Beloso, N.; Robles-Torres, D.; López-López, A.; et al. Real-world prevalence and consequences of potential drug-drug interactions in the first-wave COVID-19 treatments. J. Clin. Pharm. Ther. 2020, 46, 724-730. [CrossRef] 
89. Oguz, E.G.; Atilgan, K.G.; Cimen, S.G.; Sahin, H.; Selen, T.; Ebinc, F.A.; Cimen, S.; Ayli, M.D. COVID-19 infection in a kidney transplant recipient-special emphasis on pharmacokinetic interactions: A case report. World J. Transplant. 2020, 10, 365-371. [CrossRef] [PubMed]

90. Bishara, D.; Kalafatis, C.; Taylor, D. Emerging and experimental treatments for COVID-19 and drug interactions with psychotropic agents. Ther. Adv. Psychopharmacol. 2020, 10, 2045125320935306. [CrossRef] [PubMed]

91. Sanofi-Aventis Canada Inc. Product Monograph Including Patient Medication Information: KEVZARA ${ }^{\circledR}$, Sarilumab, Solution for subcutaneous Injection. Available online: https:/ / products.sanofi.ca/en/Kevzara-en.pdf (accessed on 1 August 2021).

92. Benfield, T.; Hospital, H.U. Efficacy and Safety of Novel Treatment Options for Adults with COVID-19 Pneumonia. Available online: https: / / ClinicalTrials.gov/show /NCT04345289 (accessed on 1 August 2021).

93. Barrett, L.; Nova Scotia Health Authority; Dalhousie University. Treatment of Moderate to Severe Coronavirus Disease (COVID19) in Hospitalized Patients; Canada, 2020. Available online: https://clinicaltrials.gov/ct2/show/NCT04321993 (accessed on 1 August 2021).

94. Sivapalasingam, S.; Lederer, D.J.; Bhore, R.; Hajizadeh, N.; Criner, G.; Hossain, R.; Mahmood, A.; Giannelou, A.; SomersanKarakaya, S.; O'Brien, M.; et al. A Randomized Placebo-Controlled Trial of Sarilumab in Hospitalized Patients with COVID-19. medRxiv 2021. [CrossRef] 